\title{
ABCB4 Positive
}

National Cancer Institute

\section{Source}

National Cancer Institute. ABCB4 Positive. NCI Thesaurus. Code C141305.

An indication that $\mathrm{ABCB} 4$ expression has been detected in a sample. 